\section{OP-477後腹膜腫痬に対する腹腔鏡下腫瘍摘除術 の臨床的検討}

\section{神戸大学大学院医学研究科外科系講座腎泌尿器科学分野 \\ 田中一志, 山口 耕平, 寺川 智章, 兵頭 洋二, \\ 村蒔 基次, 石村 武志, 原口 貴裕, 中野 雄造, \\ 三宅 秀明, 竹田 雅, 武中 篤, 藤澤 正人}

【目的】腹腔鏡下腫瘍摘除術を施行した後腹膜腫瘍の検討 を行った。【対象と方法】 2001 年 8 月から 2009 年 6 月ま での間に神戸大学病院泌尿器科にて、腹腔鏡下腫瘍摘除術 を施行した 8 例を刘象とした。性別は男性 4 例、女性 4 例、 平均年齢は 56 歳であった。腫瘍部位は大動脈周囲 3 例、 下大静脈周囲 2 例、副腎部 3 例で、右側 3 例、左側 5 例で、 1 例は再発例であった。2 例は後腹膜アプローチ、6 例は 経腹膜アプローチにて施行した。【結果】平均手術時間 212.4 分、平均出血量 $56.3 \mathrm{ml}$ で、全例腹腔鏡下に腫瘍を切 除し得た。腫瘍径の平均は $4.9 \mathrm{~cm}$ 、平均切除重量は $56.6 \mathrm{~g}$ で、 病理結果は神経鞘腫 3 例、褐色細胞腫 2 例、その他 3 例で あった。術後歩行開始、経口摂取開始はともに平均 1.1 日で、 術後合併症は認めなかった。悪性褐色細胞腫の1例のみ術 後 1 年 5 ケ月で再発を認めた。【結論】後腹膜腫瘍に対す る腹腔鏡下腫瘍摘除術は安全かつ低侵襲であり、同腫瘍に 対する有効な術式であると思われた。しかし、悪性褐色細 胞腫では術後再発を認めており、悪性が疑われる場合には 術前に十分な検討が必要と思われた。

\section{OP-478 仮想内視鏡による陰茎海綿体動脈の観察}

\section{高松赤十字病院泌尿器科}

泉 和良，川西 泰夫，間島 大博，小森 政嗣， 山中正人，山本 明，沼田 明

【目的】勃起を支配する海綿体動脈の描出はDSAや CTA，超音波検査法によって可能であった，DSA と超音 波検查法の問題点は, 血流が減少している動脈の描出が不 良であること，血流の無い動脈は描出されないことである。 すなわちこれらの検査法では臨床上, 診断の必要性が高い 動脈閉塞部や狭窄を生じている病変部を描出することがで きなかった，一方、仮想海綿体内視鏡検査では血流の有無 にかかわらず陰荎海綿体動脈を描出することが可能であ る. 仮想内視鏡による陰茎海綿体動脈の観察を行い, 3DCT angiographyとの整合性について検討した。【対象と 方法】高松赤十字病院性機能外来を受診し、勃起機能検査 として海綿体造影検查を施行した 30 例を対象とした。 こ れらの症例の画像デー夕を retrospective に解析した，仮 想内視鏡画像は 3D-CT 海綿体造影画像をワークステショ ン上で処理することにより得た．陰茎海綿体動脈の描出に ついて、仮想海綿体内視鏡と CTA との整合性を調べた。 【結果】仮想内視鏡では海綿体腔 60 腔のうち，57 腔にお いて陰茎海綿体動脈の観察が可能であった. 15 腔で C T Aでは描出されなかった動脈が確認できた。【結論】本検 査法は、動脈の内腔をみるCTA, CDU と動脈を外側から みる本検査法のコンビネーションによって、狭窄, 閉塞病 変を有する海綿体動脈のより正確な評価につながると思わ れる。

\section{OP-4793D 海綿体造影検査所見に基づいた静脈 結紮手術の経験}

\author{
高松赤十字病院泌尿器科 \\ 川西 泰夫，泉 和良，間島 大博，小森 正嗣， \\ 山中 正人, 山本 明, 沼田 明
}

【目的】静脈性勃起障害は海綿体内压が上昇した際にも静 脈流出路が開存していることを原因とする．代替治療とし てこの静脈を好理する手術が施行されてきたが有効率は不 十分であった。これには責任静脈の診断方法に問題があっ たことが関与している可能性がある.リーク部位の描出能 に優れた $3 \mathrm{DCT}$ 海綿体造影検查にもとづいた静脈結紮手: 術について報告する【対象と方法】高松赤十字病院性機能: 外来を受診した外傷による動脈性 ED 患者 6 例，手術時の 年齢は 31 歳から 35 歳. 陰茎血行再建手術の術前評価にお いて海綿体静脈閉鎖不全の合併が確認された症例である。 これらの症例に対して陰茎血行再建手術にあわせて責任静 脈の結紮を行った。【結果】 6 例とも血行再建手術は一側 の下腹壁動脈を陰茎背動脈に吻合する Michal-II 法で行っ た。観察期間は 15 ケ月から 47 ケ月で超音波による吻合部 の開存が確認された，既婚者は 3 例で 3 例とも勃起機能を 獲得し，1例は現在妊娠中，2例は児を得ていた。未婚者 は 3 例で 2 例は勃起機能を獲得したが，1 例は無効であっ た.【結論】静脈性勃起障害を合併している動脈性勃起障 害に対する血行再建手術の成績は不良であると報告されて きたが責任静脈が正確に診断され，その静脈が処理されれ ば手術治療の成功率が高まると思われた。

\section{OP-480 後期高齢者ならびに超高齢者における性 機能の検討}

\author{
北里大学医学部泌尿器科学 \\ 木村 将貴, 杉田 敦, 佐藤 威文, 志村 哲, \\ 杉田 佳子, 高口 大, 前山 良太, 土橋 正人, \\ 馬場 志郎
}

【背景】75歳以上と定義された後期高齢者は、現在本邦で は 1300 万人存在しており、超高齢化社会に突大した現在、 同高齢者の性機能を把握し生活の質を担保することは重要 と考えられる。今回、後期高齢者ならびに超高齢者を対象 とした、健康関連 QOL を含めた性機能につき検討を行っ た。【対象と方法】当院において、密封小線源療法の施行 前、または待機療法中の早期前立腺癌と診断された後期高 齢者 29 症例（超高齢者：85 歳以上の 3 症例を含む）を刘 象とした。同評価項目として UCLA-PCI、IIEF5、IPSS、 前立腺体積 $(\mathrm{PV}) 、$ 血漿テストステロンを用いた。患者年 齢は $78.9 \pm 4.8$ 歳（75-94 歳）、すべての症例においてPS (Performance status) は0であった。【結果】本検討の惠 者背景は IEEF5:5.1 \pm 6.8 点、IPSS: $9.3 \pm 6.3$ 点 QOL: 3.7 \pm 2.0 、前立腺体積: $29.7 \pm 11.8 \mathrm{cc}$ 、血漿テストステロン: 4.3 $\pm 1.9 \mathrm{ng} / \mathrm{ml}$ であった。UCLA-PCI の性機能に関するドメ インを検討すると、SF (sexual function) : $20.5 \pm 21.8$ 点、 SB (sexual bother) : $70.4 \pm 26.9$ であった。【考察】今回 検討を行った後期高齢者のうち、51.7\%で性的な欲求があ り、34.5\%でマスターベーションや挿入に充分な硬度を保 つことが可能であった。また超高齢者に扔いても、性に対 する葛藤が確認されており、他の年齢層と同様に、性機能 を考慮した医療対応が必要である。 